October 2001 - NREL/SR-510-30611

\title{
Investigation of Byproduct Application to Jet Fuel
}

\section{Final Report}

J.E. Sinor Consultants Inc.

Niwot, Colorado

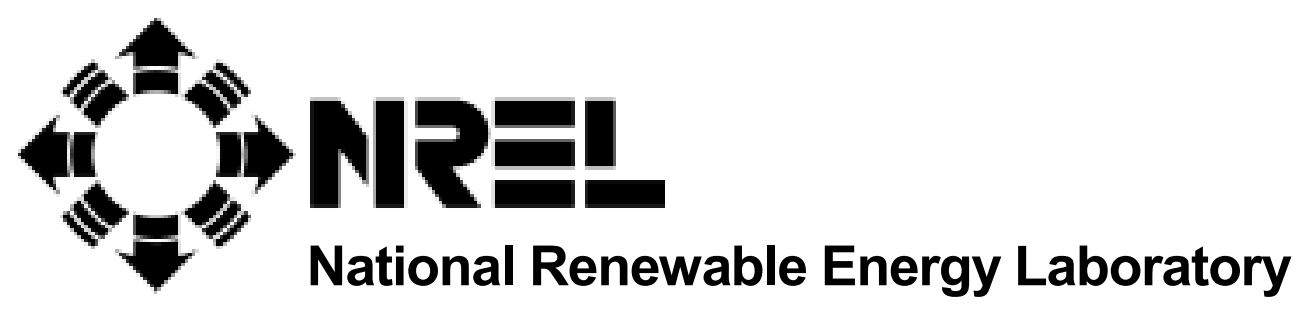

1617 Cole Boulevard

Golden, Colorado 80401-3393

NREL is a U.S. Department of Energy Laboratory

Operated by Midwest Research Institute $\bullet$ Battelle $\bullet$ Bechtel

Contract No. DE-AC36-99-G010337 
October 2001 • NREL/SR-510-30611

\title{
Investigation of Byproduct Application to Jet Fuel
}

\section{Final Report}

\author{
J.E. Sinor Consultants Inc. \\ Niwot, Colorado
}

NREL Technical Monitor: Kelly Ibsen

Prepared under Subcontract No. TXE-0-29113-01

\section{National Renewable Energy Laboratory}

1617 Cole Boulevard

Golden, Colorado 80401-3393

NREL is a U.S. Department of Energy Laboratory

Operated by Midwest Research Institute • Battelle • Bechtel

Contract No. DE-AC36-99-G010337 


\section{NOTICE}

This report was prepared as an account of work sponsored by an agency of the United States government. Neither the United States government nor any agency thereof, nor any of their employees, makes any warranty, express or implied, or assumes any legal liability or responsibility for the accuracy, completeness, or usefulness of any information, apparatus, product, or process disclosed, or represents that its use would not infringe privately owned rights. Reference herein to any specific commercial product, process, or service by trade name, trademark, manufacturer, or otherwise does not necessarily constitute or imply its endorsement, recommendation, or favoring by the United States government or any agency thereof. The views and opinions of authors expressed herein do not necessarily state or reflect those of the United States government or any agency thereof.

Available electronically at http://www.osti.gov/bridge

Available for a processing fee to U.S. Department of Energy

and its contractors, in paper, from:

U.S. Department of Energy

Office of Scientific and Technical Information

P.O. Box 62

Oak Ridge, TN 37831-0062

phone: 865.576.8401

fax: 865.576.5728

email: reports@adonis.osti.gov

Available for sale to the public, in paper, from:

U.S. Department of Commerce

National Technical Information Service

5285 Port Royal Road

Springfield, VA 22161

phone: 800.553.6847

fax: 703.605.6900

email: orders@ntis.fedworld.gov

online ordering: http://www.ntis.gov/ordering.htm

Printed on paper containing at least $50 \%$ wastepaper, including $20 \%$ postconsumer waste 


\section{CONTENTS}

INTRODUCTION AND BACKGROUND 1

DEFINITIONS 2

Distillation of Crude Oil $\quad 2$

Product Names $\quad 3$

Jet Fuel Nomenclature $\quad 3$

FUEL PROPERTIES $\quad 6$

$\begin{array}{ll}\text { Average Properties } & 6\end{array}$

$\begin{array}{ll}\text { Specification Properties } & 6\end{array}$

$\begin{array}{ll}\text { Composition } & 7\end{array}$

$\begin{array}{ll}\text { High-Temperature Stability } & 7\end{array}$

$\begin{array}{ll}\text { Freezing Point } & 7\end{array}$

Heat of Combustion $\quad 8$

$\begin{array}{lr}\text { General Requirement } & 8\end{array}$

$\begin{array}{ll}\text { Static Charges } & 8\end{array}$

RESEARCH ON ADVANCED JET FUELS 9

Fuel Stability Requirements $\quad 9$

The Rationale for JP-900 10

Intermediate Goals $\quad 12$

Thermally Stable Jet Fuels From Coal 13

Studies With Model Compounds $\quad 14$

High Energy Density Fuels $\quad 14$

DEMAND, PRODUCTION AND PRICES FOR JET FUEL 15

Demand for Jet Fuel $\quad 15$

Demand Forecast $\quad 15$

Production of Jet Fuel 15

Prices for Jet Fuel 15

CHEMICAL AND PHYSICAL PROPERTIES NEEDED FOR JET FUEL 21

$\begin{array}{ll}\text { Specifications } & 21\end{array}$

Limits on Aromatics 21

Fuels From Non-Conventional Sources $\quad 21$

Additive Requirements $\quad 24$

$\begin{array}{ll}\text { Antioxidants } & 24\end{array}$

Metal Deactivator $\quad 25$

$\begin{array}{ll}\text { Static Dissipater Additive } & 25\end{array}$

Corrosion Inhibitor $\quad 25$

Fuel System Icing Inhibitor $\quad 25$

Thermal Stability Improver Additive $\quad 25$

Fuel Lubricity $\quad 26$

CONCLUSIONS $\quad 27$

REFERENCES $\quad 28$ 


\section{LIST OF FIGURES}

1. Distillation of Crude Oil

2. Heat Sink Required as a Function of Mach Number 


\section{LIST OF TABLES}

1. Names for Petroleum Products $\quad 4$

2. Typical Jet Fuel Properties 6

3. Volatility Characteristics of Jet Fuels $\quad 7$

4. High Heat Sink Fuel Goals 10

5. Composition of Unstressed Fuels 12

6. Composition of Stressed Fuels 13

7. Jet Fuel and Total Petroleum Products Supplied 16

8. Comparison of Jet Fuel Forecasts 17

9. Refinery Net Production of Jet Fuel by PAD and Refining Districts 18

10. Refiner Sales Prices and Refiner Margins for Jet Fuel 19

11. National Fuel Price Statistics 20

12. Specifications for Civilian Aviation Turbine Fuels 22

13. Military Aviation Fuel Specifications $\quad 23$

14. Military Jet Fuels 24 


\section{Introduction and Background}

The National Renewable Energy Laboratory (NREL) has an on-going program for the conversion of biomass to ethanol. Such processes achieve less than $100 \%$ conversion, leaving a residual material consisting mostly of lignin. There is a need to find a way to convert this useless byproduct into a saleable product. Experiments have shown that it is possible to convert this material into a mixture of alkyl benzenes boiling at the high end of the gasoline boiling range. Such a material would have a high octane number and could be a useful additive to motor gasoline. It was not expected that an alkyl benzene product would also be useful as a jet fuel component. However, in or to ensure that no possibilities were overlooked, NREL asked J. E. Sinor Consultants Inc. to carry out a brief study of jet fuel characteristics and markets to determine whether any applications for an alkyl benzene product exist. 


\section{Definitions}

\section{Distillation of Crude Oil}

When crude oil enters the refinery, it is first separated into various fractions by distillation. Primary distillation takes place at atmospheric pressure and the bottom temperature is limited to between $370^{\circ} \mathrm{C}$ and $400^{\circ} \mathrm{C}$ to prevent thermal cracking.

The lowest boiling fraction, taken from the top of the distillation column, is called naphtha (see Figure 1). It is mainly processed further to make motor gasoline. Next, kerosene and special solvents boil over, followed by the so-called "gas oil" or "middle distillate" fraction which includes diesel fuel, jet fuel, and heating oil. Finally, although the bottoms fractions or residual fraction can be used as heavy boiler fuel, it is usually vacuum distilled first to yield more high-value distillate.

The boiling point ranges shown in Figure 1 do not constitute strict boundaries. Jet fuel, kerosene, No. 1 fuel oil, No. 2 fuel oil, and diesel fuel are all popular distillate products coming from $200^{\circ} \mathrm{C}$ to $315^{\circ} \mathrm{C}$ fractions of crude oil. One grade of jet fuel uses the heavy naphtha fraction, but the kerosene fraction supplies the more popular, heavier grade of jet fuel.

Figure 1

\section{Distillation of crude oil}

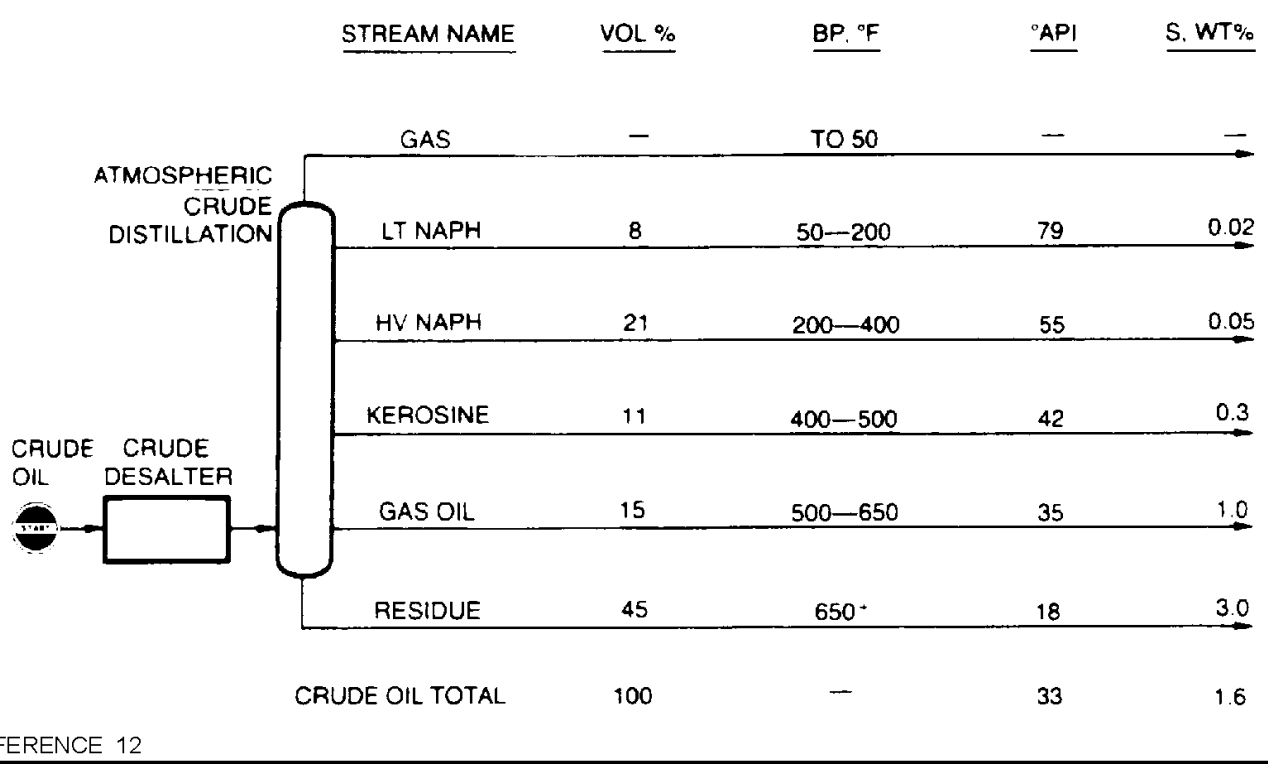




\section{Product Names}

The distinction between refined products and petrochemicals is often a subtle one. In general, when the product is a fraction from crude oil that includes a fairly large group of hydrocarbons, the fraction is classified as a refined product. Examples of refined products are: gasoline, diesel fuel, heating oils, lubricants, waxes, asphalts, and petroleum coke.

Most refined products at the consumer level are blends of several refinery streams. Product specifications determine which streams are suitable for a specific blend. Part of the difficulty of refining literature lies in the industry's use of stream names that are different from the names of the consumer products.

In contrast, when the product from crude oil is limited to only one or two specific hydrocarbons of fairly high purity, the fraction is called a petrochemical. Examples of petrochemicals are: ethylene, propylene, benzene, toluene, and styrene - to name only a few.

Consider the listing in Table 1. The names in the last column are those used at the consumer level. Yet, within a refinery, these products will be blended from portions of crude oil fractions having the names shown in the first column. Furthermore, specifications and statistics for the industry are often reported under yet another set of names - those shown in the middle column of Table 1.

Petroleum naphtha is a generic term applied to refined, partly refined or unrefined petroleum products. Naphtha can also be a combination of product streams from several refinery processes. The main uses of petroleum naphtha fall in the general area of solvents.

Kerosene originated as a straight-run (distilled) petroleum fraction that boiled over the temperature range of $205^{\circ} \mathrm{C}$ to $260^{\circ} \mathrm{C}$. In the early days of petroleum refining, some crude oils contained kerosene fractions of high quality, but other crude oils had to be thoroughly refined before a satisfactory kerosene fraction could be obtained. Kerosene is believed to be composed chiefly of hydrocarbons containing 12 to 15 carbon atoms per molecule (1). Low proportions of aromatic and unsaturated hydrocarbons are desirable to maintain the lowest possible level of smoke during burning.

Kerosene may be called coal oil to denote that it replaces stove oil (or range oil) once derived from coal. Kerosene's historical significance was first as illuminating oil for lamps that once burned sperm oil taken from whales. But today, kerosene fractions go mostly into transportation fuels such as jet fuel and highquality No. 1 heating oil.

\section{Jet Fuel Nomenclature}

Commercial kerosene was used as a fuel in early developmental work on jet aircraft in the United States. The choice of kerosene over gasoline was based on its low volatility (to avoid occurrence of vapor lock) and on its availability as a commercial product with uniform characteristics. JP-1, the first military jet fuel, was highly refined kerosene having a low freezing point $\left(-60^{\circ} \mathrm{C}\right)$. Kerosene from selected crudes high in naphtha was the only fuel having this low freezing point. As the demand for the fuel increased, the Military Petroleum Advisory Board recommended the development of a military jet fuel having greater availability in wartime than JP-1 (2). The second candidate jet fuel was JP-2, but it did not have the desired availability. JP-3 fuel was another possibility. It included the total boiling range of kerosene and gasoline. Testing demonstrated that the high vapor pressure of JP-3 (Reid Vapor Pressure [RVP] of 5 to 7 pounds per square inch [PSI]) resulted in vaporization of the fuel during climb to altitude. 


\section{Table 1}

\section{Names for Petroleum Products}

$\begin{array}{lll}\text { Crude Oil Cuts } & \text { Refinery Blends } & \text { Consumer Products } \\ \text { Gases } & \begin{array}{l}\text { Still Gases } \\ \text { Propane/Butane }\end{array} & \begin{array}{l}\text { Fuel Gas } \\ \text { Liquefied Petroleum Gas }\end{array} \\ \text { Light/Heavy Naphtha } & \begin{array}{l}\text { Motor Fuel } \\ \text { Aviation Turbine Fuel, Jet-B }\end{array} & \begin{array}{l}\text { Gasoline } \\ \text { Jet Fuel (naphtha type) }\end{array} \\ \text { Kerosene } & \text { Aviation Turbine Fuel, Jet-A } & \text { Jet Fuel (kerosene type) } \\ & \text { No. 1 Fuel Oil } & \text { Kerosene (range oil) } \\ \text { Light Gas Oil } & \text { Diesel } & \text { Auto and Tractor Diesel } \\ & \text { No. 2 Fuel Oil } & \text { Home Heating Oil } \\ \text { Heavy Gas Oil } & \text { No. 4 Fuel Oil } & \text { Commerical Heating Oil } \\ & \text { No. 5 Fuel Oil } & \text { Industiral Heating Oil } \\ \text { Bright Stock } & \text { Lubricants } \\ \text { Residuals } & \text { No. 6 Fuel Oil } & \text { Bunker C Oil } \\ & \text { Heavy Residual } & \text { Asphalt } \\ \text { Coke } & \text { Coke }\end{array}$

Source: 12

In addition, some times the fuel foamed excessively during vaporization so that large losses of liquid could occur along with the vented vapors.

To overcome the disadvantages of JP-3, JP-4 was developed in 1951, by reducing the RVP to 2 to 3 pounds. This fuel is a blend of $25 \%$ to $35 \%$ kerosene and $65 \%$ to $75 \%$ naphtha components and proved satisfactory for military requirements. During the Korean War, JP-5 fuel was developed for aircraft carriers. This is a special $\left(60^{\circ} \mathrm{C}\right)$ flash point kerosene. Because of its low volatility, it can be stored safely in outer tanks of aircraft carriers.

Commercial airline jet fuels in the United States are classified as American Society for Testing and Materials (ASTM) Jet A, A-1 and B fuels. Jet A and A-1 are kerosene type fuels. Jet B corresponds to the military JP-4 fuel and is no longer used to any significant extent.

The operation of aircraft in long-duration flights at high altitude imposes a special requirement of good low-temperature flow behavior; this need established Jet A-1, which has a freezing point of $-50^{\circ} \mathrm{C}$ (wax) as an international flight fuel. Jet $\mathrm{A}$ which has a freezing point of $-40^{\circ} \mathrm{C}$ (wax) can serve shorter domestic routes.

JP-6 was the first fuel established by the Air Force for use in supersonic aircraft. 
JP-7 is a highly refined, high thermal stability fuel developed in the 1960s to meet the high heat sink demands of the SR-71 reconnaissance aircraft (now retired). JP-7 was later designated as a high thermal stability fuel for use in a hydrocarbon-fueled Mach 4-8 missile (3).

The fuel is a complex mixture of hydrocarbons comprising mainly naphthenes, paraffins, and a maximum of $5 \%$ aromatics. It is thermally stable to $288^{\circ} \mathrm{C}$.

In the 1990s, JP-8 became the standard jet fuel for the military services. For use on ships, the Navy still uses JP-5, but all other branches of the Army, Air Force, and Navy have standardized on JP-8. The only difference between JP-5 and JP-8 is that JP-5 has a minimum flash point of $140^{\circ} \mathrm{F}$ compared to $100^{\circ} \mathrm{F}$ for JP-8. JP-8 is virtually equivalent to today's commercial Jet A-1.

Jet fuel fulfills a dual purpose in aircraft. It provides the energy and also serves as a coolant for lubricating oil and other aircraft components. Exposure of the fuel to high temperatures may cause the formation of oxidation materials (gums) that reduce the efficiency of heat exchangers and clog filters and valves in aircraft fuel-handling systems. Thermal stability is the resistance to formation of gums at high temperature. The JP-4, JP-5, JP-8 and equivalent commercial fuels have satisfactory thermal stability for aircraft operating at speeds up to about Mach 2.0. Jet aircraft operating at higher speeds, e.g., Mach 3, may expose the fuel to greater thermal stresses and, therefore, may require a more stable fuel. The development of Mach 3-4 turbojets, Mach 6-plus ramjets, and rockets using hydrocarbon fuels will pose additional demands on fuel stability. 


\section{Fuel Properties}

\section{Average Properties}

The average properties of current aircraft jet fuels are shown in Table 2. However, even fuels that fall within specification can vary widely from the averages. For example, the maximum allowable for aromatics content is $25 \%$. For JP-8 purchased from 1990 to 1996 the range was from $25 \%$ to less than $9 \%$ aromatics, with a mean of $18.2 \%$ and a standard deviation of $3.1 \%$ (4).

Additives must be effective in all of these baseline fuels to qualify for sale.

Table 2

Typical Jet Fuel Properties

$\begin{array}{lcccc}\text { Property } & \underline{\mathrm{JP}}-4 & \underline{\mathrm{JP}}-5 & \underline{\mathrm{JP}-7} & \underline{\mathrm{JP}-8 \text { (Jet A/A-1) }} \\ & & & & \\ \text { Approx. Formula } & \mathrm{C}_{8.5} \mathrm{H}_{17} & \mathrm{C}_{12} \mathrm{H}_{22} & \mathrm{C}_{12} \mathrm{H}_{25} & \mathrm{C}_{11} \mathrm{H}_{21} \\ \text { H/C Ratio } & 2.00 & 1.92 & 2.07 & 1.91 \\ \text { Boiling Range, F } & 140-460 & 360-495 & 370-480 & 330-510 \\ \text { Freeze Point, F } & -80 & -57 & -47 & -60 \text { JP-8/Jet A-1; } \\ & & & & -50 \text { Jet A } \\ \text { Flash Point, F } & -10 & 147 & 140 & 127 \\ \text { Net Heating Value, BTU/lb } & 18,700 & 18,500 & 18,875 & 18,550 \\ \text { Specific Gravity 60F } & 0.76 & 0.81 & 0.79 & 0.81 \\ \text { Critical T, F } & 620 & 750 & 750 & 770 \\ \text { Critical P, psia } & 450 & 290 & 305 & 340 \\ \text { Average Composition } & & & & \\ \quad \text { Aromatics, vol.\% } & 10 & 19 & 3 & 18 \\ \quad \text { Naphthenes } & 29 & 34 & 32 & 20 \\ \quad \text { Paraffins } & 59 & 45 & 65 & 60 \\ \quad \text { Olefins } & 2 & 2 & & 2 \\ \quad \text { Sulfur, ppm } & 370 & 470 & 60 & 490\end{array}$

Source: 4

\section{Specification Properties}

While all piston engine fuels have the same volatility but differ in combustion characteristics, jet fuels differ primarily in volatility and differences in their combustion qualities are minor. The volatility characteristics of several grades of jet fuel are shown in Table 3. For fuels in which the RVP is too low for accurate measurement, the flash point is given. This is the temperature to which a fuel must be heated to generate sufficient vapor to form a flammable mixture in air. 


\section{Table 3}

\section{Volatility Charcteristics of Jet Fuels}

$\begin{array}{lccc}\begin{array}{l}\text { Jet Fuel } \\ \text { Grade }\end{array} & \begin{array}{c}\text { Distillation } \\ \text { Range, }{ }^{\circ} \mathrm{F}\left({ }^{\circ} \mathrm{C}\right)\end{array} & \begin{array}{c}\text { RVP, } \\ \text { psia }(\mathrm{kPa}, \text { absolute })\end{array} & \begin{array}{c}\text { Flash Point, } \\ \underline{{ }^{\circ} \mathrm{F}\left({ }^{\circ} \mathrm{C}\right)}\end{array} \\ \text { JP-1 } & 325-450(163-230) & -- & 120(49) \\ \text { JP-3 } & 100-500(38-260) & 6(41) & -- \\ \text { JP-4 } & 150-500(65-260) & 2.5(17) & -- \\ \text { JP-5 } & 350-500(177-260) & -- & 150(65) \\ \text { JP-6 } & 300-500(149-260) & -- & 100(38) \\ \text { Jet A } & -- & -- & 100(38) \\ \text { Jet B } & -- & -- & 100\end{array}$

Source: 13

\section{Composition}

Production of distillate turbine fuel uses about $8 \%$ of typical crude oil input to a refinery. This percentage could be increased at added incremental costs and with a concurrent reduction in the output of motor gasoline and diesel fuel. Turbine fuel contains aromatic hydrocarbons; limits are placed on this content because of concerns about smoke and coke formation. For military jet fuels, the limit on aromatics is $25 \%$ by volume, and for commercial fuel the limit is $20 \%$ (except by mutual agreement between supplier and purchaser, in which case the content may not exceed $20 \%$ for Jet A or $22 \%$ for Jet A-1 or Jet B).

There is also a limit on sulfur content: $0.3 \%$ by weight.

\section{High-Temperature Stability}

In subsonic jets, the fuel is used to cool the engine lubricant, and the temperature of the fuel can be raised by about $93^{\circ} \mathrm{C}$. In supersonic jets, the fuel is used as a heat sink for the engine lubricant, for cabin air conditioning, and for cooling the hydraulic systems. For very-high-speed flight, the fuel may be used to cool additional engine components and critical air frame areas, such as the leading edges of wings. Therefore, depending on flight speeds and aircraft design, turbine fuels can be heated from $150^{\circ} \mathrm{C}$ to $260^{\circ} \mathrm{C}$ before they are burned. When they are heated to this degree, small amounts of solids may form, and foul the heat exchangers and clog the filters and fuel injectors. There are specifications (see Table 12) to indicate the temperature at which solids are first formed and the amount of solids formed with time.

\section{Freezing Point}

Turbine fuels must have low freezing points: $-40^{\circ} \mathrm{C}$ for Jet $\mathrm{A}$ and $-50^{\circ} \mathrm{C}$ for Jet $\mathrm{A}-1$ and Jet $\mathrm{B}$. 


\section{Heat of Combustion}

The heat of combustion of all jet fuels is about $18,400 \mathrm{BTU}$ per pound $(42.8 \mathrm{MJ} / \mathrm{kg})$. This is the net, or low heating value. A gallon of turbine fuel weighs about 6.7 pounds and thus has an energy content of about 123,000 BTU (1 liter weighs about 0.80 kilograms and has an energy content of about 34.4 MJ).

\section{General Requirement}

All jet fuels must meet the stringent performance requirements of aircraft turbine engines and fuel systems, which demand extreme cleanliness and freedom from oxidation deposits in high-temperature zones. Combustors require fuels that atomize and ignite at low temperatures, burn with adequate heat release and controlled radiation, and neither produce smoke nor attack hot turbine parts.

\section{Static Charges}

Fuels pumped through long multi-product pipelines or delivered by tanker are usually clay-filtered to ensure freedom from surfactants. Many stages of filters operate to ensure clean, dry product as the fuel moves into airport tanks, hydrant systems and finally aircraft. Because high-speed filtration can generate static electric charges, fuels may contain an electrical conductivity additive to ensure rapid dissipation of charge. 


\section{Research on Advanced Jet Fuels}

\section{Fuel Stability Requirements}

The Air Force Research Laboratory at Wright-Patterson Air Force Base has established several target fuels of higher heat sink capacity than the Air Force's current fuel, JP-8. JP-8 is limited to a maximum temperature of about $325^{\circ} \mathrm{F}$ in current aircraft.

The thermal management requirements for hypersonic aircraft are well known. As shown in Figure 2, the required fuel heat sink increases dramatically with vehicle Mach number. From the figure, it can be seen that an engine for a Mach 8 vehicle would require a heat sink from the fuel of about 1,500 BTU per pound. This level of heat sink can only be obtained from endothermic fuels, where the sensible heat sink of the fuel $(\mathrm{Cp} \Delta \mathrm{T})$ is enhanced by heat-absorbing (endothermic) reactions in the bulk fuel.

JP-7 has a thermal stability temperature limit of $290^{\circ} \mathrm{C}$, but costs about three times as much as JP-8 (4). Table 4 shows the fuel development targets. JP- $8+100$ has been demonstrated in the field in a considerable number of aircraft, while the development of JP- $8+225$ is just beginning $(3,5)$.

Petroleum industry analysts expect that the thermal stability of jet fuels may decrease somewhat in the near future as regulations requiring dramatic reductions in sulfur contents of gasoline and diesel fuels go into effect (4).

Figure 2

Heat sink required as a function of mach number lower bound - missiles, upper bound - aircraft

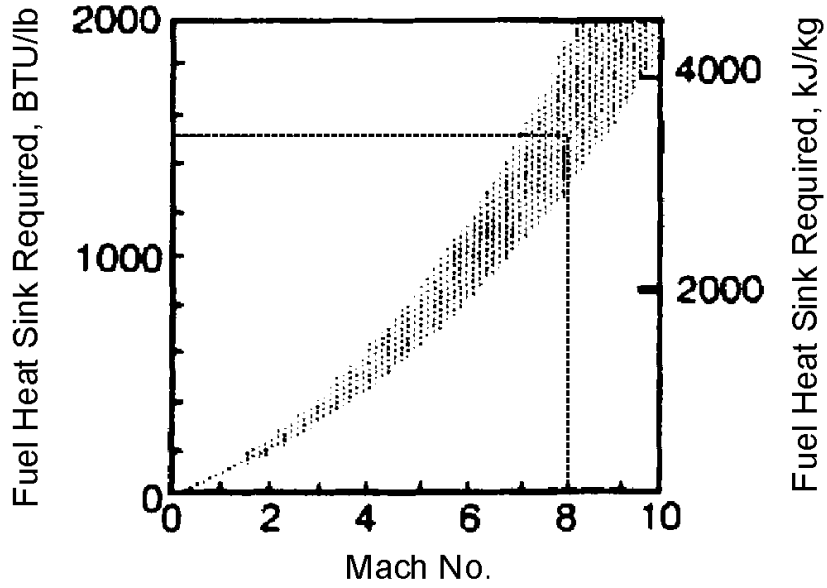


Table 4

High Heat Sink Fuel Goals

$\begin{array}{lcc}\text { Fuel } & \begin{array}{c}\text { Maximum } \\ \text { Use T, F }\end{array} & \begin{array}{c}\text { Heat Sink } \\ \text { (relative to JP-8) }\end{array} \\ \text { JP-8 } & 325 & -- \\ \text { JP-8+100 } & 425 & 1.5 \mathrm{X} \\ \text { JP-8+225 } & 550 & 2.2 \mathrm{X} \\ \text { JP-900 } & 900 & 5 \mathrm{X} \\ \text { Endothermic JP } & \mathrm{n} / \mathrm{a} & 12 \mathrm{X}\end{array}$

Source: 4

\section{The Rationale for JP-900}

The Air Force has a significant turbine engine development program, IHPTET, which has the overall goal of doubling the thrust-to-weight ratio of turbine engines. The IHPTET program studies ways to increase the engine cycle temperatures and pressures to achieve this increase in thrust-to-weight (along with component weight reduction goals). Ideally, this increase in cycle temperature would be achieved by developing more capable engine materials. However, a combination of improved materials and "cooled cooling air" may be required. In a cooled cooling air system, compressor bleed air is cooled with fuel or fan air and then used to maintain the engine materials within their temperature limits. In a recent study (6), a notional advanced engine with a turbine rotor inlet temperature of $2,100^{\circ} \mathrm{C}$ is described (compared to 1990 s technology of less than $2,100^{\circ} \mathrm{C}$ ). This notional engine uses materials expected to be available in 2010-2015 and assesses the benefits of cooled cooling air. Because of turbine cooling requirements, the baseline engine is limited to a compressor exit temperature of $760^{\circ} \mathrm{C}$ and pressure ratio of $32: 1$. The baseline system diverts almost $17 \%$ of the high-pressure air from the compressor to perform turbine cooling. With a cooled cooling air system, the cycle pressure ratio can be increased to 50, with a resulting increase in engine thrust-to-weight and decrease in specific fuel consumption. The best performing option in the study was to use the fuel as a heat sink so that the fuel temperature increased to $275^{\circ} \mathrm{C}$. This option had an increase in thrust-to-weight of $11 \%$ and a decrease in specific fuel consumption of $3.3 \%$ over the baseline system.

Thermal management system layouts that take advantage of fuel heat sink show that a system employing a $900^{\circ} \mathrm{F}$-capable $\left(482^{\circ} \mathrm{C}\right)$ fuel would be optimum for land-based aircraft applications.

A JP-900 fuel will have to achieve both oxidative and pyrolytic stability, properties which seem to be inversely related (7). Oxidative instability is defined as deposit formation on engine surfaces shortly after the fuel reacts with its dissolved oxygen (usually between $180^{\circ} \mathrm{C}$ to $220^{\circ} \mathrm{C}$ ). Pyrolytic instability, on the other hand, is an anaerobic deposit formation on engine surfaces that occurs at temperatures above $450^{\circ} \mathrm{C}$. 
The very chemical and structural characteristics that make hydrogen donors effective thermal stabilizers in the pyrolytic regime also accentuate the susceptibility to oxidation in the so-called autoxidation regime between $150^{\circ} \mathrm{C}$ to $300^{\circ} \mathrm{C}(8)$.

Recent work at the Pennsylvania State University (PSU) has shown that by understanding the mechanisms for the oxidative and thermal decomposition of jet fuels, it should be possible to rationally design additives that will achieve JP-900 (7).

Any additive (including antioxidants, anti-icers, metal deactivators, and detergents) that is susceptible to disintegration into free radicals in the pyrolytic regime can enhance degradation at temperatures above $400^{\circ} \mathrm{C}$ with potentially disastrous consequences. Classic antioxidants, such as, for example, the sterically hindered phenols that operate well in the autoxidation regime, actually promote free radical reactions in the pyrolytic regime. In other words, the additive introduced to prevent degradation of the fuel in storage and at moderately elevated temperatures can adversely affect the efficacy of the additive introduced to retard the formation of carbonaceous solids at high temperatures.

Such additives are most likely to be structurally simple and will not contain long aliphatic side groups or other moieties that can cleave and produce free radicals above $400^{\circ} \mathrm{C}(8)$. It is important that additives introduced to prevent the autoxidative degradation of the fuel also prevent degradation of the highly susceptible hydrogen donor stabilizers by suppressing the normal autoxidation pathway. Accordingly, when temperatures rise to those of the pyrolytic regime, the hydrogen donors will be free to suppress pyrolytic degradation via the usual $\mathrm{H}$-transfer mechanism.

The PSU research has been focused on finding potential oxygen scavengers for use in jet fuels (8). The rationale is that if molecular oxygen is eliminated from the fuel, most of the problems are solved. The scavenger should protect both the fuel and the hydrogen donor in the autoxidative regime, and the reaction product between the scavenger molecule and oxygen should be reasonably stable and not generate free radicals in the pyrolytic regime. Potential oxygen scavengers include phosphines and like molecules.

Triphenylphosphine (TPP) appears to fulfill all the requirements, but test results were not encouraging.

However, dimethylphenylphosphine (DMPP) gave some encouraging results. Unfortunately, DMPP is a liquid with a strong stench and is unpleasant to handle.

This led PSU researchers to the alternative dialkylarylphosphine, dicyclohexylphenyl-phosphine (DCHPP).

DCHPP at a level of $200 \mathrm{ppm}$ appears to protect fuel mixtures from oxidation at $250^{\circ} \mathrm{C}$ for periods of up to at least 12 hours. Moreover, at $425^{\circ} \mathrm{C}$, carbonaceous deposits are not observed until after 6 hours. This is encouraging and warrants further investigation using JP-900 type jet fuels. 


\section{Intermediate Goals}

The Air Force's JP- $8+100$ program increased the thermal stability of JP- 8 by $100^{\circ} \mathrm{F}$ by developing an additive package. The JP- $8+100$ additive package consists of a dispersant, a metal deactivator and an antioxidant. The next intermediate goal, being worked on currently, is JP-8+225. This fuel would have a thermal stability of $225^{\circ} \mathrm{F}$ better than JP-8, which would allow operation at a temperature of up to $288^{\circ} \mathrm{C}$ $\left(550^{\circ} \mathrm{F}\right)$. An additive approach is being pursued here also (5).

In other tests carried out at PSU four fuels were "stressed" in a reactor: JP-8, kerosene, dearomatized hydrotreated light cycle oil and Norpar-13. Norpar-13 is an industrial solvent manufactured by Exxon Chemical Company consisting of straight-chain alkanes ranging from $\mathrm{C}_{11}$ to $\mathrm{C}_{15}$. Norpar-13 was included as a model fuel.

Table 5 shows the composition of the four fuels before stressing. Kerosene, JP-8 and Norpar-3 all contain a high percentage of straight-chained alkanes. Kerosene and JP-8 also contain high percentages of branched-chain alkanes. In contrast, dearomatized hydrotreated light cycle oil has a high percentage of cyclic alkanes, which have been shown to be more thermally stable than straight-chain alkanes.

JP-8 exhibited the greatest carbon deposit formation, followed by Norpar-13. The dearomatized hydrotreated light cycle oil exhibited significantly less deposit formation than the other two fuels. The kerosene exhibited the least amount of deposit formation.

The fact that JP-8 produces significantly more deposit than the other three fuels studied is thought to be largely due to the high percentage of aromatic compounds present in the fuel. Alkyl aromatics have been shown to degrade easily. Additionally, JP-8 contains an additive package that is thought to decrease the thermal stability of the fuel.

Table 5

\section{Composition of Unstressed Fuels (Weight Percent)}

\begin{tabular}{|c|c|c|c|c|}
\hline Compounds & $\underline{\text { Kerosene }}$ & $\underline{\mathrm{JP}}-8$ & $\underline{\mathrm{DA} / \mathrm{HT} \text { LCO }}$ & Norpar-13 \\
\hline n-Alkanes & $50 \%$ & $37 \%$ & $13 \%$ & $>99.9 \%$ \\
\hline iso-Alkanes & $15 \%$ & $42 \%$ & $16 \%$ & $<0.1 \%$ \\
\hline Alkenes & $5 \%$ & $7 \%$ & $5 \%$ & $<0.1 \%$ \\
\hline Cycloalkanes & $13 \%$ & $8 \%$ & $66 \%$ & $<0.1 \%$ \\
\hline Aromatics & $9 \%$ & $5 \%$ & $<0.1 \%$ & $<0.1 \%$ \\
\hline Hydroaromatics & $8 \%$ & $1 \%$ & $<0.1 \%$ & $<0.1 \%$ \\
\hline Other & $<1 \%$ & $<1 \%$ & $<1 \%$ & $<0.1 \%$ \\
\hline
\end{tabular}

Source: 14 
The compositions of the stressed fuels are shown in Table 6. The most notable change is an increase in the concentration of alkenes. Primary alkenes predominate, indicating that many of the alkenes are formed by $\beta$-scission decompositions. The fraction of $n$-alkanes and iso-alkanes drops upon stressing.

Dearomatized hydrotreated light cycle oil exhibits a drop in the concentration of cycloalkanes and a rise in the amount of hydroaromatics. Dearomatized hydrotreated light cycle oil contains a great deal of decalin, which can act as a hydrogen donor. As decalin undergoes dehydrogenation reactions, it forms tetralin and then naphthalene. This accounts for the increase in hydroaromatics. The drop in cycloalkanes may be attributed to cracking reactions that affect alkyl cycloalkanes, resulting in lighter cycloalkanes and light alkenes or alkanes.

Although dearomatized hydrotreated light cycle oil, which has a high content of cycloalkanes, was expected to be the most thermally stable fuel of those tested, kerosene was the most stable fuel under the conditions used. The kerosene employed contains a substantial percentage of hydroaromatic compounds, which have been shown to increase thermal stability in a deoxygenated environment.

Table 6

\section{Composition of Stressed Fuel (Weight Percent)}

\begin{tabular}{|c|c|c|c|c|}
\hline$\underline{\text { Compounds }}$ & $\underline{\text { Kerosene }}$ & $\underline{\mathrm{JP}-8}$ & $\underline{\mathrm{DA} / \mathrm{HT} \mathrm{LCO}}$ & $\underline{\text { Norpar-13 }}$ \\
\hline n-Alkanes & $42 \%$ & $29 \%$ & $9 \%$ & $72 \%$ \\
\hline iso-Alkanes & $12 \%$ & $31 \%$ & $12 \%$ & $5 \%$ \\
\hline Alkenes & $15 \%$ & $22 \%$ & $18 \%$ & $22 \%$ \\
\hline Cycloalkanes & $13 \%$ & $7 \%$ & $56 \%$ & $<1 \%$ \\
\hline Aromatics & $9 \%$ & $8 \%$ & $<0.1 \%$ & $<1 \%$ \\
\hline Hydroaromatics & $9 \%$ & $2 \%$ & $3 \%$ & $<0.1 \%$ \\
\hline Other & $<1 \%$ & $1 \%$ & $2 \%$ & $<1 \%$ \\
\hline
\end{tabular}

Source: 14

\section{Thermally Stable Jet Fuels From Coal}

There are some unique compositional advantages to using coal-derived liquids for making advanced jet fuels, with respect to the high-temperature thermal stability. Compared to conventional petroleumderived jet fuels, the coal-derived jet fuels display greater thermal stability at temperatures above $400^{\circ} \mathrm{C}$ in terms of much lower degree of decomposition and significantly fewer solid deposits. This is because coal-derived jet fuels are rich in cycloalkanes and the aromatic compounds in coal-derived jet fuels can be dominated by hydroaromatic structures (9). Cycloalkanes are more stable than the n-alkanes with the same or lower carbon number, and the stability of alkylated cycloalkanes decreases with increasing length or carbon number in the side chain. At temperatures above $400^{\circ} \mathrm{C}$, decomposition of long-chain paraffins in jet fuels is dominated by radical-chain reactions. Hydroaromatic compounds such as tetralin are hydrogen donors that can serve as radical scavengers in pyrolytic reactions that inhibit the thermal decomposition of reactive hydrocarbons. 
Coal-derived JP-8C fuel has been shown to be thermally stable at temperatures up to $482^{\circ} \mathrm{C}$ or $900^{\circ} \mathrm{F}(9)$.

\section{Studies With Model Compounds}

At PSU, the thermal stability of coal- and petroleum-derived jet fuels and the associated model compounds decahydronaphthalene and n-tetradecane was studied under both batch and flow conditions. Under batch reactor conditions, the decahydronaphthalene showed excellent thermal stability up to $500^{\circ} \mathrm{C}$, whereas the n-tetradecane started its cracking process at around $450^{\circ} \mathrm{C}$. Flow reactor studies mirrored the thermal decomposition of the model compounds, although the cracking appeared at higher bulk fuel temperatures. The thermal behavior of the experimental jet fuels also confirmed that the paraffinic portion of the fuels is the main reason for thermal fuel degradation.

The current jet fuels are petroleum-derived and consequently rich in linear alkanes, which are highly susceptible to pyrolytic cracking, resulting in coking. Therefore, the thermal stability of a jet fuel in the pyrolytic regime can be greatly enhanced by utilizing liquids rich in cycloalkanes.

An additional problem with jet fuels is the presence of dissolved oxygen from air, which reacts with the fuel during the autoxidative regime $\left(150^{\circ} \mathrm{C}\right.$ to $\left.250^{\circ} \mathrm{C}\right)$ before the fuel and its oxygenated reaction products enter the pyrolytic regime $\left(400^{\circ}\right.$ to $\left.500^{\circ} \mathrm{C}\right)$. Accordingly, a recent study compares the thermal stability of coal- and petroleum-derived jet fuels and associated model compounds, as they go through the autoxidative and pyrolytic regime, both under batch and flow conditions (10). Differences in chemical reactivity between linear- and cyclo-alkane model compounds are related to the superior thermal stability of coalderived jet fuels.

\section{HIGH ENERGY DENSITY FUELS}

At one time the military expended considerable effort on fuels with a high energy density. Of particular interest were the naphthenic (cycloparaffinic) fuels that can be produced from shale oil. However, almost all aircraft today are weight-limited on takeoff so a reduction in fuel volume is not of high value. Missile and rocket applications, such as cruise missiles, are volume constrained and could make use of high energy density, but these are limited applications in terms of the amount of fuel involved. 


\section{Demand, Production, and Prices for Jet Fuel}

\section{Demand for Jet Fuel}

The historic demand for jet fuel in the United States is given in Table 7. As of 1999, jet fuel demand was 1.67 million barrels per day. This accounts for approximately $8.5 \%$ of total petroleum products demand.

Total military demand for jet fuel is about 228,000 barrels per day. This is nearly the same demand as existed in 1985 and is a little less than $14 \%$ of current total jet fuel demand, whereas in 1985 it was nearly $19 \%$ of total demand.

\section{Demand Forecast}

Summarized in Table 8 are various forecasts for jet fuel demand in the years 2010 and 2020. All show continuing increases in jet fuel demand through 2020. The forecast rate of growth to 2020 varies from $1.5 \%$ per year to $3.5 \%$ per year. For the period $2010-2020$, all forecasts use a growth rate of about $3 \%$ per year.

\section{Production of Jet Fuel}

Production of jet fuel at United States refineries, by fuel type and by Petroleum Administration for Defense (PDA) district and by state is illustrated in Table 9. These data are for November 2000.

\section{Prices for Jet Fuel}

Historical fuel price statistics for Jet-A are given in Table 10. Sales for resale, that is, wholesale sales, are those made to purchasers who are other than ultimate consumers. Sales to end users are those made directly to the ultimate consumer, including bulk sales customer, such as agriculture, industry, and utilities, as well as residential and commercial customers.

Current prices for Jet-A used in private aircraft at various airports are listed in Table 11. These prices vary widely from airport to airport. 
Table 7

Jet Fuel and Total Petroleum

Products Supplied by Year

\begin{tabular}{|c|c|c|}
\hline Year & Jet Fuel & Total \\
\hline 1950 & 0.00 & 6.46 \\
\hline 1951 & 0.00 & 7.02 \\
\hline 1952 & 0.05 & 7.27 \\
\hline 1953 & 0.09 & 7.60 \\
\hline 1954 & 0.13 & 7.76 \\
\hline 1955 & 0.15 & 8.46 \\
\hline 1956 & 0.20 & 8.78 \\
\hline 1957 & 0.22 & 8.81 \\
\hline 1958 & 0.27 & 9.12 \\
\hline 1959 & 0.33 & 9.53 \\
\hline 1960 & 0.37 & 9.80 \\
\hline 1961 & 0.42 & 9.98 \\
\hline 1962 & 0.49 & 10.40 \\
\hline 1963 & 0.52 & 10.74 \\
\hline 1964 & 0.56 & 11.02 \\
\hline 1965 & 0.60 & 11.51 \\
\hline 1966 & 0.67 & 12.08 \\
\hline 1967 & 0.82 & 12.56 \\
\hline 1968 & 0.95 & 13.39 \\
\hline 1969 & 0.99 & 14.14 \\
\hline 1970 & 0.97 & 14.70 \\
\hline 1971 & 1.01 & 15.21 \\
\hline 1972 & 1.02 & 16.37 \\
\hline 1973 & 1.04 & 17.31 \\
\hline 1974 & 0.98 & 16.65 \\
\hline 1975 & 0.99 & 16.32 \\
\hline 1976 & 0.98 & 17.46 \\
\hline 1977 & 1.02 & 18.43 \\
\hline 1978 & 1.04 & 18.85 \\
\hline 1979 & 1.07 & 18.51 \\
\hline 1980 & 1.06 & 17.06 \\
\hline 1981 & 1.01 & 16.06 \\
\hline 1982 & 1.01 & 15.30 \\
\hline 1983 & 1.05 & 15.23 \\
\hline 1984 & 1.18 & 15.73 \\
\hline 1985 & 1.22 & 15.73 \\
\hline 1986 & 1.31 & 16.28 \\
\hline 1987 & 1.38 & 16.67 \\
\hline 1988 & 1.45 & 17.28 \\
\hline 1989 & 1.49 & 17.33 \\
\hline 1990 & 1.52 & 16.99 \\
\hline 1991 & 1.47 & 16.71 \\
\hline 1992 & 1.45 & 17.03 \\
\hline 1993 & 1.47 & 17.24 \\
\hline 1994 & 1.53 & 17.72 \\
\hline 1995 & 1.51 & 17.72 \\
\hline 1996 & 1.58 & 18.31 \\
\hline 1997 & 1.60 & 18.62 \\
\hline 1998 & 1.62 & 18.92 \\
\hline 1999 & 1.67 & 19.39 \\
\hline
\end{tabular}

Source: 15 


\section{Table 8}

\section{Comparison of Jet Fuel Forecasts}

\begin{tabular}{|c|c|c|c|c|c|c|}
\hline \multirow[b]{3}{*}{ Projection } & \multicolumn{3}{|c|}{ Annual Energy Outlook 2001} & \multirow{2}{*}{\multicolumn{3}{|c|}{ Other Forecasts }} \\
\hline & \multirow[b]{2}{*}{$\underline{\text { Reference }}$} & \multirow{2}{*}{$\begin{array}{l}\text { Low World } \\
\text { Oil Price }\end{array}$} & \multirow{2}{*}{$\begin{array}{l}\text { High World } \\
\text { Oil Price }\end{array}$} & & & \\
\hline & & & & $\underline{\text { WEFA }}$ & $\underline{\text { GRI }}$ & $\underline{\mathrm{DRI}}$ \\
\hline 2010 & & & & & & \\
\hline $\begin{array}{l}\text { World Oil Price } \\
(1999 \$ / b b l)\end{array}$ & 21.37 & 15.10 & 26.66 & 18.48 & 18.17 & 18.65 \\
\hline $\begin{array}{l}\text { Jet Fuel Demand, } \\
\text { million bpd }\end{array}$ & 2.18 & 2.20 & 2.16 & 1.92 & 2.20 & 2.37 \\
\hline 2020 & & & & & & \\
\hline $\begin{array}{l}\text { World Oil Price } \\
(1999 \$ / b b l)\end{array}$ & 22.41 & 15.10 & 28.42 & 20.41 & NA & 21.16 \\
\hline $\begin{array}{l}\text { Jet Fuel Demand, } \\
\text { million bpd }\end{array}$ & 2.88 & 2.91 & 2.84 & 2.58 & NA & 3.16 \\
\hline
\end{tabular}




\section{Table 9}

\section{Refinery Net Production of Jet Fuel by PAD and Refining District (Data for Month of November 2000, Thousand Barrels)}

$\begin{array}{ccc}\begin{array}{c}\text { Naphtha } \\ \text { Type }\end{array} & \begin{array}{c}\text { Kerosene Type } \\ \text { Military }\end{array} & \begin{array}{c}\text { Kerosene Type } \\ \text { Commercial }\end{array}\end{array}$

PAD District I

East Coast

Appalachian No. 1

0

2,926

AD District II

IN, IL, KY

MN, WI, SD, ND

$\mathrm{OK}, \mathrm{KS}, \mathrm{MO}$

PAD District III

TX Inland

TX Coast

LA Coast

N. LA, AR

NM

PAD Districts IV, V

Rocky Mountain

West Coast

0

0

39

11

5,289

189

902

45

928

0

1,326

0

307

10,737

1,447

10,851

363

218

43
199

0

0

153

1,247

711

1

10,552

Source: 17 


\section{Table 10}

\section{Refiner Sales Prices and Refiner Margins \\ For Jet Fuel (Cents per Gallon)}

$\begin{array}{ccccc}\text { Year } & \begin{array}{c}\text { Sales Price } \\ \text { to Resellers }\end{array} & \begin{array}{c}\text { Sales Price } \\ \text { to End Users }\end{array} & \begin{array}{c}\text { Refiner } \\ \text { Margin }\end{array} \\ 1983 & & & \\ 1984 & 85.4 & 87.8 & 16.4 \\ 1985 & 83.0 & 84.2 & 14.9 \\ 1986 & 79.4 & 79.6 & 15.8 \\ 1987 & 49.5 & 52.9 & 14.9 \\ 1988 & 53.6 & 54.3 & 11.2 \\ 1989 & 49.5 & 51.3 & 14.6 \\ 1990 & 58.3 & 59.2 & 15.5 \\ 1991 & 77.3 & 76.6 & 24.4 \\ 1992 & 65.0 & 65.2 & 19.6 \\ 1993 & 60.5 & 61.0 & 16.5 \\ 1994 & 57.7 & 58.0 & 18.6 \\ 1995 & 53.4 & 53.4 & 16.3 \\ 1996 & 53.9 & 54.0 & 12.9 \\ 1997 & 64.6 & 65.1 & 15.3 \\ 1998 & 61.3 & 61.3 & 16.0 \\ 1999 & 45.0 & 45.2 & 15.2 \\ & 53.8 & 53.8 & 12.2\end{array}$

Source: 18 
Table 11

\section{National Fuel Price Statistics}

(Dollars per Gallon, March 27, 2001)

\begin{abstract}
$\underline{\text { Region }}$
USA -- 48 States

Northwest Region

Southwest Region

N Central Region

S Central Region

E Central Region

Northeast Region

Southeast Region
\end{abstract}

Source: 19

\begin{tabular}{|c|c|c|c|}
\hline$\underline{\text { High }}$ & Average & Low & Difference \\
\hline 3.60 & 2.42 & 1.48 & 2.12 \\
\hline 2.99 & 2.42 & 1.76 & 1.23 \\
\hline 3.29 & 2.46 & 1.59 & 1.70 \\
\hline 2.99 & 2.36 & 1.48 & 1.51 \\
\hline 3.11 & 2.30 & 1.57 & 1.54 \\
\hline 3.31 & 2.44 & 1.72 & 1.59 \\
\hline 3.60 & 2.52 & 1.75 & 1.85 \\
\hline 3.33 & 2.46 & 1.52 & 1.81 \\
\hline
\end{tabular}

2.12

23

.70

1.54

59

1.81 


\section{Chemical and Physical Properties Needed for Jet Fuel}

\section{Specifications}

Specifications for Jet-A are published in ASTM D1655 (11). Specifications for JP-8 are contained in MIL-T-83133E. Summaries of the two are given in Tables 12 and 13, respectively.

The chief differences between the two are in the additives package used.

Mil Spec 83133 covers three variations of JP-8 according to the additives used (Table 14).

\section{Limits on Aromatics}

Although made up of many different hydrocarbons, jet fuels consist essentially of four general types of compounds: paraffins (including isoparaffins), cycloparaffins or naphthenes, aromatics, and olefins. The proportion of each compound type varies with the different types of crude oils and the processing needed to produce the fuel. A typical fuel will contain hundreds of different compounds. In general, paraffin hydrocarbons offer the most desirable combustion cleanliness characteristics for jet fuels. Naphthenes are the next most desirable hydrocarbons for this use.

Although olefins generally have good combustion characteristics, their poor gum stability usually limits their use in aircraft turbine fuels to about $1 \%$ by volume or less. Aromatics generally have the least desirable combustion characteristics for aircraft turbine fuel. In aircraft turbines they tend to burn with a smoky flame and release a greater proportion of their chemical energy as undesirable thermal radiation than the other hydrocarbons. Naphthalenes or bicyclic aromatics produce more soot, smoke, and thermal radiation than monocyclic aromatics and are, therefore, the least desirable hydrocarbon class for aircraft jet fuel use. Thus, Jet A is limited to $20 \%$ maximum aromatics and JP- 8 is limited to $25 \%$ by volume. Naphthalene content is limited to $3 \%$ for the same reason.

Except for the restrictions on aromatics, the proportions of hydrocarbon types are not directly controlled. In fact, not even the source of the feedstock is constrained, other than that it must be from petroleum, tar sands, oil shale or mixtures thereof. The requirements for density, energy content, freeze point and hydrogen content favor paraffinic- or isoparaffinic-based fuel. The hydrocarbon constituents of most jet fuels are primarily normal or isoparaffins ( $50 \%$ to $70 \%$ by volume) and cycloparaffins $(20 \%$ to $40 \%$ by volume). See Table 3.

\section{Fuels From Non-Conventional Sources}

Jet fuels containing synthetic hydrocarbons have been previously allowed under ASTM Specification D 1655. However, the fraction of synthetic hydrocarbons was not limited, and there were no requirements or restrictions placed on either these hydrocarbons or the final blend. It has been recognized that synthetic blends represent a potential departure from experience and from key assumptions on which the fuel property requirements defined in Table 12 have been based. 
Table 12

Specifications for Domestic Aviation Turbine Fuels

Property

\section{Composition}

Acidity, total mg KOH/g, max

Aromatics, vol.\%, max

Sulfur, mercaptan, wt.\%, max

Sulfur, total wt. $\%$, max

Volatility

Distillation Temp., ${ }^{\circ} \mathrm{C}$

$10 \%$ Recovered, temp., max

$20 \%$ Recovered, temp., max

$50 \%$ Recovered, temp., max

90\% Recovered, temp., max

Final Boiling Point, temp., max

Distillation Residue, \%, max

Distillation Loss, \%, max

Flash Point, ${ }^{\circ} \mathrm{C}$, min

Density at $15^{\circ} \mathrm{C}, \mathrm{kg} / \mathrm{m}^{3}$

Vapor Pressure, $38^{\circ} \mathrm{C}, \mathrm{kPa}$, max

\section{Fluidity}

Freezing Point, ${ }^{\circ} \mathrm{C}$, max

Viscosity $-20^{\circ} \mathrm{C}, \mathrm{mm}^{2} / \mathrm{s}$, max

\section{Combustion}

Net Heat of Combustion, MJ/kg, min One of the Following Requirements Shall be Met:

Luminometer Number, min

Smoke Point, mm, min

Smoke Point, $\mathrm{mm}$ and

Naphthalenes, vol.\%, max

Corrosion

Copper Strip, $2 \mathrm{~h}$ at $100^{\circ} \mathrm{C}$

Thermal Stability JFTOT

( $2.5 \mathrm{~h}$ at control temp. of $260^{\circ} \mathrm{C}$ min)

Filter Pressure Drop, mm Hg, max

Tube Deposits Less Than

\section{Contaminants}

Existent Gum, mg/100 mL, max

Water Reaction: Interface Rating, max

Additives

Electrical Conductivity, $\mathrm{pS} / \mathrm{m}$
Jet A or Jet A-1

$\underline{\text { Jet B }}$

$\begin{array}{cc}0.10 & -- \\ 25 & 25 \\ 0.003 & 0.003 \\ 0.30 & 0.3\end{array}$

205

--

145

report

report

300

1.5

1.5

38

$775-840$

$-$

-40 Jet $A^{*}$

$-50$

-47 Jet A-1*

8.0

42.8

42.8

45

45

25

18

3.0

25

18

3.0

$\begin{array}{ll}\text { No. } 1 & \text { No. } 1\end{array}$

$\begin{array}{cc}25 & 25 \\ 3 & 3\end{array}$

No Peacock or Abnormal Color Deposits

$\begin{array}{cc}7 & 7 \\ 1 b & 1 b\end{array}$

see Table 14

see Table 14

** $* *$

*Other freezing points may be agreed upon between supplier and purchaser.

**If electrical conductivity additive is used, the conductivity shall not exceed $450 \mathrm{pS} / \mathrm{m}$ at the point of use of the fuel.

Source: 11 
Table 13

\section{Military Aviation Fuel Specification}

Color Saybolt

Total Acid Number, mg KOH/gm

a

Aromatics, vol.\%

0.015

Sulfur, total, mass \%

25.0

Sulfur Mercaptan, mass \% OR

0.30

Doctor Test

Distillation Temp., ${ }^{\circ} \mathrm{C}$

Initial Boiling Point

$10 \%$ Recovered

$20 \%$ Recovered

$50 \%$ Recovered

90\% Recovered

End Point

0.002

negative

Residue, vol.\%

Loss, vol.\%

Flash Point, ${ }^{\circ} \mathrm{C}$

Density or Gravity

Density, $\mathrm{kg} / \mathrm{L}$ at $15^{\circ} \mathrm{C}$ OR

Gravity, API at $60^{\circ} \mathrm{F}$

Freezing Point, ${ }^{\circ} \mathrm{C}$

Viscosity, at $-20^{\circ} \mathrm{C}, \mathrm{mm}^{2} / \mathrm{s}$

Net Heat of Combustion, MJ/kg

205

a

a

300

1.5

1.5

38

0.775

0.840

Hydrogen Content, mass\%

13.4

25.0

19.0

Copper Strip Corrosion, $2 \mathrm{hr}$ at $100^{\circ} \mathrm{C}\left(212^{\circ} \mathrm{F}\right)$

Change in Pressure Drop, $\mathrm{mm} \mathrm{Hg}$

Heater Tube Deposit, visual rating

Existent Gum, mg/100 ml

Particulate Matter, $\mathrm{mg} / \mathrm{L}$

Filtration Time, minutes

Water Reaction Interface Rating

Water Separation Index

Fuel System Icing Inhibitor, vol.\%

Fuel Electrical Conductivity, pS/m

${ }^{\mathrm{a}}$ To be reported, not limited

${ }^{\mathrm{b}}$ Peacock or abnormal color deposits result in failure

${ }^{\mathrm{c}}$ The conductivity must be between 150 and $450 \mathrm{pS} / \mathrm{m}$ for F-34 (JP-8) and between

50 and $450 \mathrm{pS} / \mathrm{m}$ for F-35, at ambient temperature. In the case of JP-8+100, the conductivity limit must be between 150 and $700 \mathrm{pS} / \mathrm{m}$ at ambient temperature.

${ }^{\mathrm{d}}$ The minimum microseparometer rating using a Micro-Separometer (MSEP) shall be as follows:

$\underline{\text { JP-8 Additives }}$

$\underline{\text { MSEP Rating, min. }}$

Antioxidant (AO), Metal Deactivator (MDA)

90

AO, MDA, and Fuel System Icing Inhibitor (FSII)

85

$\mathrm{AO}, \mathrm{MDA}$, and Corrosion Inhibitor/Lubricity Improver (CI/LI)

0.15 $\mathrm{AO}, \mathrm{MDA}, \mathrm{FSII}$ and $\mathrm{CI} / \mathrm{LI}$

80

Source: 20 
Table 14

Military Jet Fuels

$\underline{\text { NATO Code No./Grade }}$

F-35

F-34 (JP-8)

JP- $8+100$

\section{Description}

Kerosene type turbine fuel which will contain a static dissipator additive, may contain antioxidant, corrosion inhibitor/lubricity improver, and metal deactivator but will not contain fuel system icing inhibitor.

Kerosene type turbine fuel which will contain a static dissipator additive, corrosion inhibitor/lubricity improver, and fuel system icing inhibitor, and may contain antioxidant and metal deactivator.

F-34 (JP-8) type kerosene turbine fuel which contains a thermal stability improver additive.

Source: 20

The longer-term strategy is to revise Specification D 1655 to fully encompass fuels from nonconventional sources, but this has yet to be defined. As an interim solution, ASTM has deemed necessary to recognize, on an individual basis, fuels from non-conventional sources whose performance complies with the intent of this specification.

The Sasol semi-synthetic fuel, a blend of conventionally produced kerosene and a synthetic kerosene is recognized as meeting the requirements of Specification D 1655.

\section{Additive Requirements}

For JP-8, the following additives are allowed or required.

\section{Antioxidants}

Immediately after processing and before the fuel is exposed to the atmosphere (i.e., during rundown into feed/batch tankage), an antioxidant is added in order to prevent the formation of gums and peroxides after manufacture. The concentration of antioxidant added must be not less than $17.2 \mathrm{mg}$ nor more than $24.0 \mathrm{mg}$ of active ingredient per liter of fuel. The following antioxidant formulations are approved:

- 2,6-di-tert-butyl-4-methylphenol

- 6-tert-butyl-2,4-dimethylphenol

- 2,6-di-tert-butylphenol 
- $\quad 75 \%$ minimum 2,6-di-tert-butylphenol

$25 \%$ maximum tert-butylphenols and tri-tert-butylphenols

- $\quad 72 \%$ minimum 6-tert-butyl-2,4-dimethylphenol

28\% maximum tert-butyl-methylphenols and tert-butyl-dimethylphenols

- $\quad 55 \%$ minimum 2,4-dimethyl-6-tert-butylphenol and

$15 \%$ minimum 2,6-di-tert-butyl-4-methylphenol and

$30 \%$ maximum mixed methyl and dimethyl tert-butylphenols

\section{Metal Deactivator}

A metal deactivator, N,N'-disalycylidene-1,2-propanediamine, may be blended into the fuel. The concentration of active material used on initial batching of the fuel at the refinery must not exceed $2.0 \mathrm{mg} / \mathrm{L}$. Cumulative addition of metal deactivator when redoping the fuel, must not exceed $5.7 \mathrm{mg} / \mathrm{L}$.

\section{Static Dissipater Additive}

An additive is blended into the fuel in sufficient concentration to increase the conductivity of the fuel to within the range specified in Table 13 at the point of injection. The following electrical conductivity additive is approved: Stadis 450 marketed by Octel America Inc.

\section{Corrosion Inhibitor}

A corrosion inhibitor conforming to $M I L-P R F-25017$ shall be blended into the F-34 (JP-8) grade fuel by the contractor. The corrosion inhibitor additive is optional for F-35.

The conductivity of the fuel must be between 150 and $450 \mathrm{pS} / \mathrm{m}$ for F-34 (JP-8) and between 50 and $450 \mathrm{pS} / \mathrm{m}$ for F-35, at ambient temperature. In the case of JP-8+100, the conductivity limit must be between 150 and $700 \mathrm{pS} / \mathrm{m}$ at ambient temperature.

\section{Fuel System Icing Inhibitor}

The use of a fuel system icing inhibitor is mandatory for NATO F-34 (JP-8) and shall conform to MILDTL-85470.

\section{Thermal Stability Improver Additive}

Personnel at the operating location must request written approval from the cognizant authority if they wish to add a thermal stability improver additive to the fuel.

Qualified thermal stability improver additives are SPEC AID 8Q462, and AeroShell Performance Additive 101. 


\section{Fuel Lubricity}

Aircraft/engine fuel system components and fuel control units rely on the fuel to lubricate their moving parts. The effectiveness of a jet fuel as a lubricant in such equipment is referred to as its lubricity. Differences in fuel system component design and materials result in varying degrees of equipment sensitivity to fuel lubricity. Similarly, jet fuels vary in their level of lubricity. In-service problems experienced due to low lubricity have ranged in severity from reductions in pump flow to unexpected mechanical failure leading to in-flight engine shutdown.

Severe hydroprocessing removes trace components, resulting in fuels that tend to have lower lubricity than straight-run or wet-treated fuels. Certain additives, for example, corrosion inhibitors, can improve the lubricity and are widely used in military fuels. They have been used occasionally in civil jet fuel to overcome aircraft problems but only as a temporary remedy while improvements to the fuel system components or changes to fuel were achieved. Because of their polar nature, these additives can have adverse effects on ground base filtration systems and on fuel water separation characteristics.

Some modern aircraft fuel system components have been designed to operate on low lubricity fuel. Problems are more likely to occur when aircraft operations are confined to a single refinery source where fuel is severely hydroprocessed and where there is no co-mingling with fuels from other sources during distribution between refinery and aircraft. 


\section{Conclusion}

A brief examination of jet fuel specifications shows that aromatic compounds are generally undesirable components of jet fuel. The major reason is their unfavorable combustion behavior in aircraft turbine engines. Aromatic fuels result in smoke in the exhaust along with coke formation and overheating in the combustor. Therefore, jet fuel specifications limit the amount of aromatics allowed in both military and civilian jet fuels.

Military research directed toward jet fuels of the future has focused on high energy density fuels and on fuels with high temperature stability. Only the latter is currently being pursued in a significant way. Although alkyl benzenes might have a reasonably high energy density and good temperature stability, the unfavorable combustion characteristics completely bar their use as a bulk fuel.

Even if use as a bulk fuel is not allowable, it is possible that small amounts could be employed as an additive. Useful changes in fuel properties would have to result. A review of currently used additives and their chemical composition did not reveal any applications for alkyl benzenes.

We therefore conclude that there is no potential market for alkyl benzenes as jet fuel components or additives. 


\section{References}

1. Kirk-Othmer Concise Encyclopedia of Chemical Technology, Wiley Interscience, 1985.

2. Van Nostrand's Scientific Encyclopedia, Sixth edition, Van Nostrand Rheinhold, 1983.

3. Faulkner, R.F., Weber, J.W., "Hydrocarbon Scramjet Propulsion System Development, Demonstration and Application," AIAA-99-4922, November 1999.

4. Edwards, T., "System Drivers for High Heat Sink Fuels," Symposium on Structure of Jet Fuels VI, ACS, August 2000.

5. Zabarnick, S., "Investigation of Fuel Additives for a JP-8+225 Jet Fuel Using the Quartz Microbalance," Symposium on Structure of Jet Fuels VI, ACS, August 2000.

6. Bruening, G.B., Chang, W.S., "Cooled Cooling Air Systems for Turbine Thermal Management," ASME 99-GT-14, June 1999.

7. Beaver, B., Gao, L., Coleman M., "JP-900: Strategies and Mechanisms for Oxygen Scavenging," Symposium on Structure of Jet Fuels VI, ACS, August 2000.

8. Sobkowiak, M., Yang, R., Song, C., Coleman, M., Beaver, B., "The Oxidative Susceptibility of High Temperature Stable Jet Fuels: Ramifications and Strategies," Symposium on Structure of Jet Fuels VI, ACS, August 2000.

9. Song, C., Schobert, H., "An Integrated Approach to Utilization of Coal for Specialty Chemicals, Materials and Advanced Jet Fuels," $220^{\text {th }}$ ACS National Meeting, August 2000.

10. Anderson, J., Strohm, J., Song, C., "Comparison of the Thermal Stability of Coal-Derived Jet Fuels, in the Autoxidative and Pyrolytic Regimes Under Batch and Flow Conditions," $219^{\text {th }}$ ACS National Meeting, San Francisco, March 2000.

11. ASTM D-1655, Standard Specific for Aviation Turbine Fuels, ASTM, October 2000.

12. Riegel's Handbook of Industrial Chemistry, Ninth Edition, Van Nostrand Rheinhold, 1992.

13. McGraw-Hill Encyclopedia of Science \& Technology, McGraw-Hill, 1992.

14. Roan, M., Goodeluinas, J., Bacak, J., Boehman, A., "Flow Reactor Studies of Potential PetroleumDerived Jet Fuels," Symposium on Structure of Jet Fuels VI, ACS, August 2000.

15. Annual Energy Review 1999, Energy Information Administration, 2000.

16. Annual Energy Outlook 2001, Energy Information Administration, December 2000.

17. Petroleum Supply Monthly, Energy Information Administration, January 2001.

18. Annual Energy Review 1999, Energy Information Administration, 2000.

19. National Fuel Price Statistics, Fillups Flyer Fuel Finder, fillupflyer.com/stats.

20. Turbine Fuels, Aviation, Kerosene Types, NATO F-34 (JP-8), NATO F-35, and JP-8+100, Military Specification MIL-DTL-83133E, April 1999. 


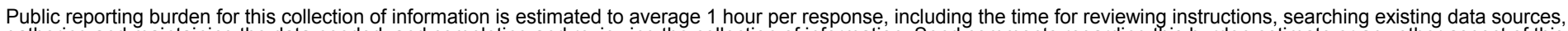

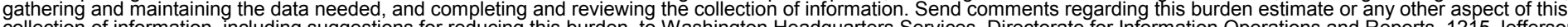

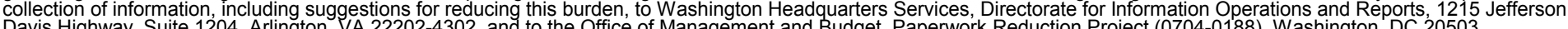

Davis Highway, Suite 1204, Arlington, VA 22202-4302, and to the Office of Management and Budget, Paperwork Reduction Project (0704-0188), Washington, DC 20503.
1. AGENCY USE ONLY (Leave blank)
2. REPORT DATE
October 2001
3. REPORT TYPE AND DATES COVERED
Subcontract Report Final Report

4. TITLE AND SUBTITLE
Investigation of Byproduct Application to Jet Fuel: Final Report

6. $\operatorname{AUTHOR}(\mathrm{S})$
7. PERFORMING ORGANIZATION NAME(S) AND ADDRESS(ES)

J.E. Sinor Consultants Inc.

6964 North $79^{\text {th }}$ Street Suite 1

Niwot, Colorado 80544
5. FUNDING NUMBERS BFP17110

8. PERFORMING ORGANIZATION REPORT NUMBER

9. SPONSORING/MONITORING AGENCY NAME(S) AND ADDRESS(ES)

National Renewable Energy Laboratory

1617 Cole Blvd.

Golden, CO 80401-3393
10. SPONSORING/MONITORING AGENCY REPORT NUMBER NREL/SR-510-30611

11. SUPPLEMENTARY NOTES

NREL Technical Monitor: Kelly Ibsen

12a. DISTRIBUTION/AVAILABILITY STATEMENT National Technical Information Service

U.S. Department of Commerce

5285 Port Royal Road

Springfield, VA 22161

13. ABSTRACT (Maximum 200 words)

Subcontract report in which J.E. Sinor Consultants Inc. reported on a brief study of jet fuel characteristics and markets to determine whether any applications for an alkyl benzene product exist.

14. SUBJECT TERMS

Jet fuel; alkyl benzene; J.E. Sinor

15. NUMBER OF PAGES

16. PRICE CODE

17. SECURITY CLASSIFICATION OF REPORT Unclassified

18. SECURITY CLASSIFICATION OF THIS PAGE Unclassified
19. SECURITY CLASSIFICATION OF ABSTRACT Unclassified
20. LIMITATION OF ABSTRACT

UL 